\title{
Interphase cytogenetic and AgNOR analyses of hydatidiform moles
}

\author{
M Watanabe, M Ghazizadeh, H Konishi, T Araki
}

\begin{abstract}
Aim-To determine the potential value of interphase cytogenetic and argyrophilic nucleolar organiser region (AgNOR) analyses in the diagnosis and classification of hydatidiform moles. Methods-Serial tissue sections from 37 hydatidiform moles, histologically classified as 11 complete and 15 partial, and from 11 hydropic abortuses were examined by in situ hybridisation using digoxigenin labelled probes specific for chromosomes $1, X$, and $Y$, and a one step silver staining method. The percentages of diploid and triploid nuclei, and the mean number of AgNORs for each tissue were determined.
\end{abstract}

Results-Interphase cytogenetics showed that eight of the 11 cases $(73 \%)$ each of complete mole and hydropic abortus had diploid pattern and the three remaining cases $(27 \%)$ of each group were triploid. Two of the triploid complete moles and one of the triploid hydropic abortuses were revised to partial moles and one remaining triploid complete mole was revised to hydropic abortus. Of the 15 partial moles, nine $(60 \%)$ were triploid, and six $(40 \%)$ were diploid. These diploid cases were revised to three complete moles and three hydropic abortuses. There was a significant difference $(p<0.0001)$ between the mean (SD) AgNOR count in partial mole (5.11 (0.91)) versus hydropic abortus $(3.79(0.90))$ and complete mole $(3.39(0.97))$. The total of 15 triploid cases showed a high mean AgNOR count of $5.24(0.73)$. Also, after reclassification, eight of the nine partial moles $(89 \%)$ had a mean AgNOR count of $\geqslant 5$. The results of analyses by the two methods were closely correlated.

Conclusions-Interphasecytogeneticanalysis using chromosome specific probes and AgNOR count provides a valuable approach for ploidy analysis in histological sections of hydatidiform moles and helps to resolve difficult cases.

(f Clin Pathol 1998;51:438-443)

Keywords: hydatidiform moles; interphase cytogenetics; AgNOR count; ploidy

Correspondence to: Dr M Ghazizadeh, Central Institute for Electron Microscopic Researches, Nippon Medical School, 1-1-5 Sendagi, Bunkyo-ku, Tokyo 113, Japan; email: ciem@nms.ac.jp

Accepted for publication 4 March 1998 centa with hydropic swelling of chorionic villi and excessive trophoblastic cell proliferation.
Hydatidiform moles are classified as complete moles and partial moles. The distinction between complete moles, partial moles, and non-molar hydropic abortuses is important because complete moles are more likely to progress to persistent trophoblastic disease than partial moles, with risk of metastases and choriocarcinoma. $^{2}$

Complete mole is characterised by gross hydropic swelling of most of the chorionic villi with loss of intravillous vascularity and absence of a fetus. It occurs as a result of fertilisation of an empty egg devoid of maternal chromosomes by a single spermatozoon (in most cases) that duplicates its 23,X chromosomal content to produce $46, \mathrm{XX}$, or by two spermatozoa (about $25 \%$ of cases) to produce a dispermic $46, \mathrm{XX}$ or $46, \mathrm{XY}$ conceptus. ${ }^{3-6}$ Partial mole is characterised by two groups of chorionic villi, one being normal in size and the other showing hydropic swelling which is often focal. Villous capillaries containing nucleated fetal red blood cells are usually present. Other evidence of a fetus such as chorionic plate, amnion, cord, and embryonic or fetal tissue may be found. The trophoblastic cell proliferation is focal and mild. Partial mole results from the fertilisation of a normal egg by one or two spermatozoa, receiving two copies of the paternal genome to become triploid with $69, \mathrm{XXY}$ in $70 \%$, $69, \mathrm{XXX}$ in $27 \%$, and $69, \mathrm{XYY}$ in $3 \%$ of cases. ${ }^{78}$ Non-molar hydropic abortuses usually do not manifest gross villous swelling. They contain oedematous villi covered by attenuated trophoblast. However, distinction between complete mole, partial mole, and non-molar hydropic abortus based on histology alone may sometimes be difficult.

Karyotype analysis has shown that complete mole is usually diploid, partial mole is mostly triploid, and hydropic abortus is often diploid, ${ }^{6} 79$ thus providing useful information on the classification of hydatidiform mole. Karyotype analysis, however, requires tissue culture and may result in a selective growth of wrong cell populations. Flow cytometry has been successfully used to assess nuclear ploidy in hydatidiform mole and hydropic abortus cases. $^{10-12}$ These methods have the intrinsic problem that they may include undesired cell populations and they lack the advantage of simultaneous assessment of tissue morphology. Recently, in situ hybridisation using chromosome specific probes has been shown to be a reproducible and valid method of detecting numerical chromosome aberrations and assessing nuclear ploidy in routinely processed, paraffin embedded tissue sections. ${ }^{13-16}$ The method had been referred to as "interphase 

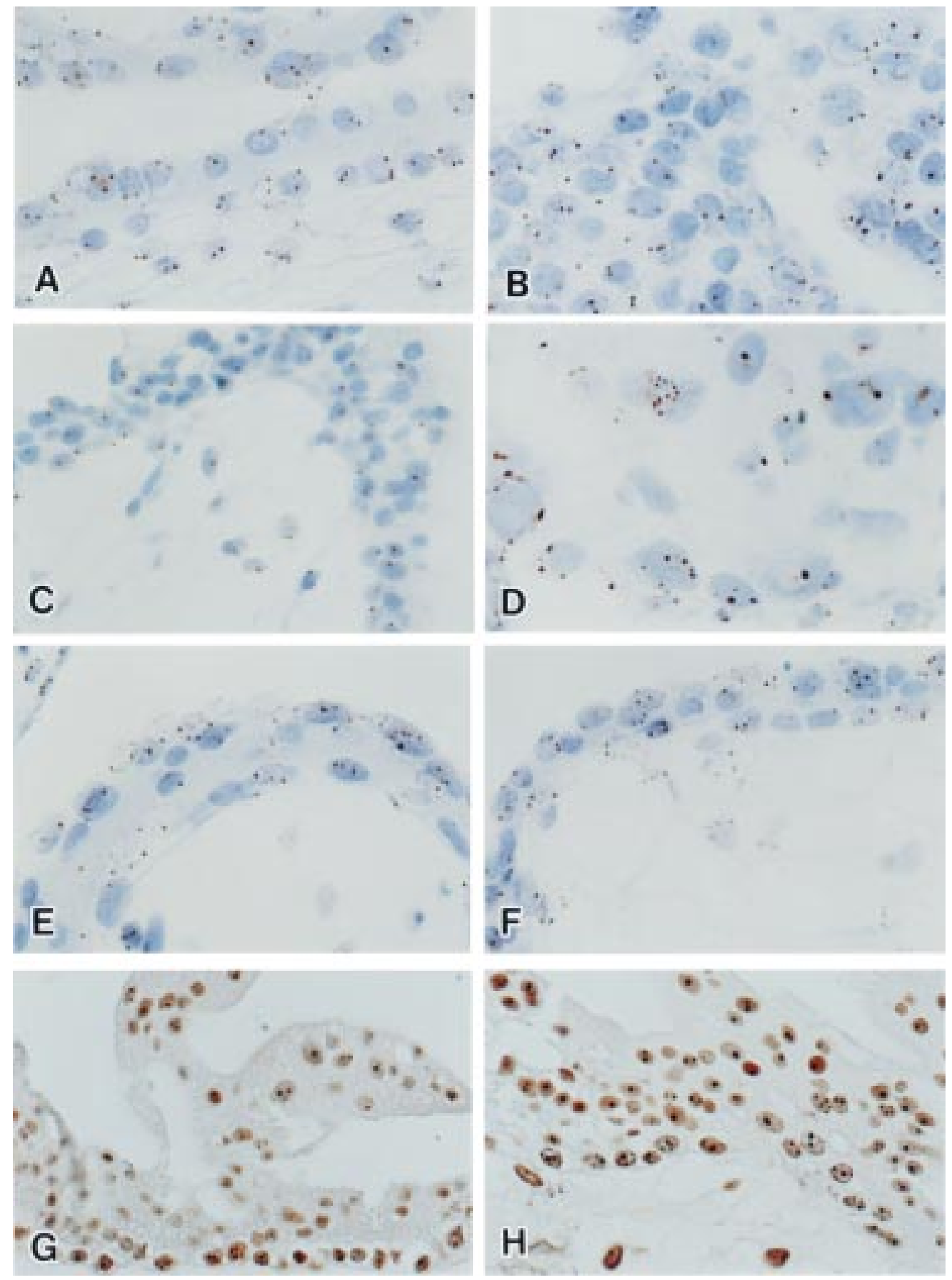

Figure 1 The results of in situ hybridisation using digoxigenin labelled probes for chromosomes $1, X$, and $Y$, and $A g N O R$ staining in hydatidiform moles. In complete moles, the majority of villous cell nuclei showed two copies of chromosomes 1 $(A)$ and $X(B)$, and in one case one copy of chromosomes $X$ and $Y(C)$. In addition, hyperplastic trophoblast areas showed marked nuclear atypia and multiple copies of chromosomes 1 or X (D). In partial moles, the majority of villous cell nuclei showed three copies of chromosomes $1(E)$ and $X(F)$. AgNOR staining showed that in complete mole many nuclei of the villous trophoblastic cells contained three or fewer AgNOR dots $(G)$, while in partial mole they had more than three $(H)$. Non-molar hydropic abortus showed nuclei with mostly less than three AgNOR dots (not shown). Magnification, $\times 354$.

cytogenetics." 1718 These suggest that ploidy analysis plays an important role in the diagnosis and classification of molar disease.

Nucleolar organiser regions (NOR) are segments of DNA that transcribe to ribosomal RNA and are located on the short arms of the acrocentric chromosomes 13,14, 15, 21, and $22 .{ }^{1920}$ The number of NOR reflects the synthetic activity of cells. ${ }^{18}{ }^{19}$ A colloidal silver stain is generally used to visualise NOR in tissue sections; these are referred to as AgNOR. ${ }^{19}$ Studies of AgNOR in breast carcinoma and placental trophoblastic tissues have shown a close correlation between the mean AgNOR count and nuclear ploidy. ${ }^{21-23}$

In this study, we examined serial tissue sections from histologically diagnosed complete moles, partial moles, and hydropic abortuses for nuclear ploidy by interphase cytogenetics using probes specific for chromosomes 1, X, and Y, and AgNOR counts. The results obtained by the two methods were then compared to determine their potential value in the diagnosis and classification of hydatidiform mole. 
Table 1 Ploidy analysis of hydatidiform moles and hydropic abortuses by interphase cytogenetics using probes specific for chromosomes $1, X$, and $Y$, and silver stained nuclear organiser region (AgNOR) count

\begin{tabular}{|c|c|c|c|c|c|c|}
\hline \multirow[b]{2}{*}{ Case No } & \multirow{2}{*}{$\begin{array}{l}\text { Histological } \\
\text { diagnosis }\end{array}$} & \multicolumn{3}{|c|}{ Chromosome ploidy (No) } & \multirow{2}{*}{$\begin{array}{l}\text { Mean AgNOR } \\
\text { count }\end{array}$} & \multirow{2}{*}{$\begin{array}{l}\text { Revised } \\
\text { classification }\end{array}$} \\
\hline & & 1 & $X$ & $Y$ & & \\
\hline 1 & $\mathrm{CM}$ & 2 & 2 & 0 & 3.45 & $\mathrm{CM}$ \\
\hline 2 & $\mathrm{CM}$ & 2 & 2 & 0 & 2.31 & $\mathrm{CM}$ \\
\hline 3 & $\mathrm{CM}$ & 3 & 3 & 0 & 3.52 & HA \\
\hline 4 & $\mathrm{CM}$ & 2 & 2 & 0 & 2.60 & $\mathrm{CM}$ \\
\hline 5 & $\mathrm{CM}$ & 2 & 2 & 0 & 4.13 & $\mathrm{CM}$ \\
\hline 6 & $\mathrm{CM}$ & 3 & 3 & 0 & 5.11 & PM \\
\hline 7 & $\mathrm{CM}$ & 2 & 2 & 0 & 2.11 & $\mathrm{CM}$ \\
\hline 8 & $\mathrm{CM}$ & 2 & 2 & 0 & 3.20 & $\mathrm{CM}$ \\
\hline 9 & $\mathrm{CM}$ & 2 & 1 & 1 & 4.15 & $\mathrm{CM}$ \\
\hline 10 & $\mathrm{CM}$ & 3 & 3 & 0 & 4.32 & PM \\
\hline 11 & $\mathrm{CM}$ & 2 & 2 & 0 & 2.40 & $\mathrm{CM}$ \\
\hline 12 & PM & 2 & 2 & 0 & 4.21 & $\mathrm{CM}$ \\
\hline 13 & PM & 2 & 2 & 0 & 5.60 & HA \\
\hline 14 & PM & 3 & 3 & 0 & 6.22 & PM \\
\hline 15 & PM & 3 & 2 & 1 & 5.33 & PM \\
\hline 16 & PM & 2 & 1 & 1 & 4.52 & HA \\
\hline 17 & PM & 3 & 3 & 0 & 5.65 & PM \\
\hline 18 & $\mathrm{PM}$ & 3 & 3 & 0 & 4.86 & PM \\
\hline 19 & PM & 2 & 2 & 0 & 3.45 & $\mathrm{CM}$ \\
\hline 20 & PM & 3 & 3 & 0 & 6.20 & PM \\
\hline 21 & PM & 3 & 3 & 0 & 5.32 & PM \\
\hline 22 & $\mathrm{PM}$ & 2 & 2 & 0 & 3.40 & $\mathrm{CM}$ \\
\hline 23 & $\mathrm{PM}$ & 3 & 3 & 0 & 5.30 & PM \\
\hline 24 & PM & 3 & 3 & 0 & 6.25 & PM \\
\hline 25 & PM & 2 & 1 & 1 & 4.78 & HA \\
\hline 26 & PM & 3 & 2 & 1 & 5.65 & $\mathrm{PM}$ \\
\hline 27 & HA & 2 & 2 & 0 & 2.45 & HA \\
\hline 28 & HA & 2 & 1 & 1 & 3.55 & HA \\
\hline 29 & HA & 3 & 3 & 0 & 5.25 & PM \\
\hline 30 & HA & 2 & 1 & 1 & 2.86 & HA \\
\hline 31 & HA & 2 & 2 & 0 & 3.59 & HA \\
\hline 32 & HA & 3 & 3 & 0 & 4.75 & HA \\
\hline 33 & HA & 2 & 2 & 0 & 2.76 & HA \\
\hline 34 & HA & 2 & 2 & 0 & 3.80 & HA \\
\hline 35 & HA & 3 & 3 & 0 & 4.95 & HA \\
\hline 36 & HA & 2 & 2 & 0 & 3.90 & HA \\
\hline 37 & HA & 2 & 2 & 0 & 3.85 & HA \\
\hline
\end{tabular}

CM, complete mole; PM, partial mole; HA, hydropic abortus. Chromosome copy number in most nuclei from villous trophoblatic and stromal cells.

\section{Methods}

TISSUES

Tissue specimens from histologically classified complete moles $(\mathrm{n}=11)$, partial moles $(\mathrm{n}=$ $15)$, and hydropic abortuses $(n=11)$ were studied. The tissues were obtained following curettage for suspected molar pregnancy or missed abortion. Gestational period varied from eight to 16 weeks. The tissues were fixed in $10 \%$ formalin and embedded in paraffin by standard methods. Serial paraffin sections of 6 $\mu \mathrm{m}$ thicknesses were mounted on silane coated glass slides and incubated in an oven at $60^{\circ} \mathrm{C}$ overnight. A section from each tissue was stained with haematoxylin and eosin, and reviewed to verify the diagnosis. Histological criteria for the diagnosis were those reported in detail by Szulman and Surti ${ }^{7}$ and Szulman et $a l,{ }^{24}$ and recently tested by Paradinas et al. ${ }^{25}$

DNA PROBES AND ANTIBODY REAGENT

DNA probes for chromosomes $1, \mathrm{X}$, and $\mathrm{Y}$ were obtained from Boehringer Mannheim $\mathrm{GmbH}$, Germany. The probes were labelled in vitro in the presence of digoxigenin-11-dUTP by nick translation of the plasmids pUC1.77 (isolated from human satellite III DNA) for chromosome $1,{ }^{26} \mathrm{pDMX} 1$ for chromosome $\mathrm{X},{ }^{27}$ and $\mathrm{pHY} 2.1$ for chromosome $\mathrm{Y}^{28}$ Under stringent conditions, the probes hybridise in situ to the (peri)centromeric region of chromosome 1 , centromeric region of chromosome $\mathrm{X}$, and the tip of the long (q) arm of chromosome Y. The probes fragment length distribution showed a maximum of 200-500 bases. Sheep antidigoxigenin ( $\mathrm{Fab}$ fragments) labelled with peroxidase (Boehringer Mannheim) was employed to detect digoxigenin.

IN SITU HYBRIDISATION

Interphase cytogenetic analysis by in situ hybridisation using chromosome specific probes was performed according to a protocol optimised for routine paraffin sections as described by Hopman et al. ${ }^{13}$ We incorporated microwave pretreatment of the paraffin sections to enhance signal detectability by in situ hybridisation..$^{29}$ The sections were deparaffinised by immersion in two changes of xylene for 10 minutes each, followed by absolute ethanol for 10 minutes. Endogenous peroxidase activity in tissue sections was quenched by immersion in $1 \% \mathrm{H}_{2} \mathrm{O}_{2}$ in methanol for 30 minutes, and the sections were rehydrated in $90 \%, 80 \%$, and $70 \%$ ethanols and rinsed in Tris- $\mathrm{HCl}$ buffer (TBS), $\mathrm{pH}$ 7.6. The slides were then placed in a Coplin jar containing $0.01 \mathrm{M}$ citrate buffer, $\mathrm{pH} 6.0$, and heated for five minutes in a microwave oven (model MRO-M55, Hitachi, Tokyo, Japan) with operating frequency of $2450 \mathrm{MHz}$ and $990 \mathrm{~W}$ power output. After cooling to room temperature, the slides were rinsed in TBS, and incubated in $1 \mathrm{M}$ sodium thiocyanate (Sigma, St Louis, Missouri, USA) at $80^{\circ} \mathrm{C}$ for $10 \mathrm{~min}$ utes to denature proteins and permeabilise the tissue sections, rinsed in TBS, and digested with $1 \mathrm{mg} / \mathrm{ml}$ pepsin (Sigma) in $0.2 \mathrm{M} \mathrm{HCl}$ at $37^{\circ} \mathrm{C}$. Pepsin digestion time was optimised for each section while preserving acceptable morphology. Most sections required five minutes' digestion with a range of three to eight minutes. Hybridisation was considered to be satisfactory when more than $90 \%$ of cells contained signals. The slides were then rinsed thoroughly in TBS, dehydrated in $70 \%, 80 \%, 90 \%$, and absolute ethanol, air dried, and heated at $80^{\circ} \mathrm{C}$ in an oven for 30 minutes. The sections were prehybridised for 15 minutes at $80^{\circ} \mathrm{C}$ with $50 \mathrm{ml}$ of a mixture of $60 \%$ formamide in $2 \times$ SSC $(0.3$ $\mathrm{M} \mathrm{NaCl}$ and $30 \mathrm{mM} \mathrm{Na}$ citrate, $\mathrm{pH} 7.5$ ) containing $10 \%$ dextran sulphate, $50 \mathrm{ng} / \mu \mathrm{l}$ herring sperm DNA, and $50 \mathrm{ng} / \mu \mathrm{l}$ baker's yeast. After washes in $2 \times$ SSC, the sections were hybridised with the same prehybridisation mixture but containing $1 \mathrm{ng} / \mu \mathrm{l}$ of the digoxigenin labelled DNA probe to either chromosome $1, \mathrm{X}$, or $\mathrm{Y}$ for 10 minutes at $80^{\circ} \mathrm{C}$ and overnight at $37^{\circ} \mathrm{C}$ in a moist chamber. The slides were then stringently washed with a solution of $60 \%$ formamide in $2 \times$ SSC and $0.05 \%$ Tween-20 for five minutes three times, and TBS with $0.05 \%$ Tween-20 for five minutes three times to remove unbound probes. Following hybridisation, the sections were incubated with 1:20 normal sheep serum for 30 minutes to block non-specific binding sites and 1:50 peroxidase labelled sheep antidigoxigenin for one hour at room temperature, washed with TBS containing $0.05 \%$ Tween20 , and reacted with $0.05 \%$ diaminobenzidine and $0.01 \% \mathrm{H}_{2} \mathrm{O}_{2}$ in TBS, pH 7.6, for $10 \mathrm{~min}-$ 


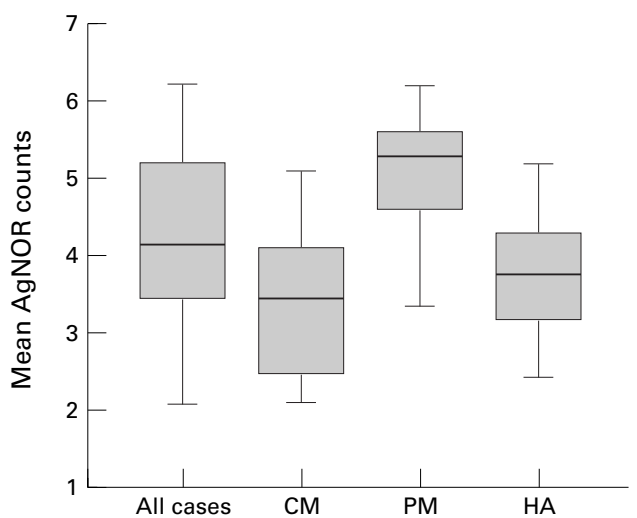

Figure 2 Boxplot of the mean (SD) AgNOR counts for all cases $(4.20(1.19) ; n=37)$ and for complete $(3.39$ $(0.97) ; n=11)$ and partial (5.11 (0.91); $n=15)$ hydatidiform moles (CM and PM), and non-molar hydropic abortus (HA; $3.79(0.90) ; n=11)$. Differences between the means for $P M$ versus $C M$ and $H A$ are significant (one factor ANOVA; $p<0.0001$ ) (lines through boxes indicate 50th centiles).

utes to visualise the signals. The reaction was stopped by washes with distilled water, and the sections were lightly stained with Mayer's haematoxylin (10 seconds) and mounted using Mount-Quick (Daido Sangyo Co, Tokyo, Japan).

EVALUATION OF HYBRIDISED SECTIONS

Hybridisation was considered adequate when more than $90 \%$ of cells contained signals. Hybridised sections were assessed essentially as described previously. ${ }^{13-15}$ Criteria for counting signals were: (1) overlapping interphase nuclei were excluded; (2) signals of nearly similar size were counted; (3) split spots were counted as one signal; and (4) weak signals were excluded. The interobserver variability in assessing the signals was less than $8 \%$. The number of signals present in 100 nuclei from the villous trophoblastic cells and stromal cells per section was counted. The percentage of nuclei having no, one, two, three, and more than three signals for each chromosome was determined. Maternal cells such as decidual or inflammatory cells present in each tissue served as internal controls of diploid XX cells, and paraffin sections from a benign prostatic hyperplasia and male lymphocytes were used as Y chromosome controls.

NOR STAINING

Histochemical staining for NOR was performed according to a method described previously. ${ }^{31}$ Briefly, tissue sections were deparaffinised in xylene and rehydrated in graded ethanol series to PBS. After microwave heating of the sections, as described above for in situ hybridisation, and cooling down to room temperature, they were incubated with a standard colloidal silver staining solution consisting of one part of a $2 \%$ gelatin in $1 \%$ aqueous formin acid solution mixed with two parts of a $25 \%$ aqueous silver nitrate solution for 30 minutes at room temperature in the dark. The sections were thoroughly washed in distilled water and immersed in a $5 \%$ solution of sodium thiosulphate for five minutes to remove artefactual silver granules. After washes in distilled water, the sections were dehydrated in ethanol series to xylene and mounted using Mount-Quick. AgNOR appeared as intranuclear black dots. Controls included endothelial and stromal cells present in each tissue section.

AgNOR QUANTIFICATION

The number of AgNOR dots was counted in 100 villous trophoblastic cell nuclei per tissue section. AgNOR were counted in comparable tissue areas as evaluated by in situ hybridisation in serial sections from the same tissues. All intranuclear silver stained dots were counted at $1000 \times$ magnification. Careful focusing was made to resolve clustered black dots into a discernible number of discrete dots for counting. The mean and standard deviation of the number of AgNOR per nucleus for each lesion were determined. The counting procedure was performed twice and the mean inter- and intraobserver variation was less than $9 \%$.

\section{STATISTICAL ANALYSIS}

Differences between the mean AgNOR counts of complete mole, partial mole, and hydropic abortus were assessed by one factor analysis of variance (ANOVA). A p value of $<0.05$ was considered as significant. Interphase cytogenetic and AgNOR results were compared using Spearman rank correlation coefficient.

\section{Results}

INTERPHASE CYTOGENETIC ANALYSIS

In the villi of complete mole, most nuclei had two copies of chromosomes 1 (fig 1A) and X (fig 1B), and in one case one copy of chromosomes X and Y (fig 1C). The hyperplastic trophoblast areas showed marked nuclear atypia frequently associated with multiple copies of chromosomes 1 and X (fig 1D). The fraction of such nuclei ranged from $10 \%$ to $35 \%$. In the villi of partial mole, three copies of chromosomes 1 (fig $1 \mathrm{E}$ ), and $\mathrm{X}$ (fig $1 \mathrm{~F}$ ), were found. Table 1 summarises the results. Overall, the findings in eight of the 11 cases $(73 \%)$ each of complete mole and hydropic abortus were consistent with diploidy. The remaining three cases $(27 \%)$ of each group showed triploid patterns. Two of the triploid complete moles and one of the triploid hydropic abortuses were revised to partial mole. The remaining triploid complete mole was revised to hydropic abortus. Of the 15 cases of partial mole, nine $(60 \%)$ were triploid and six $(40 \%)$ were diploid. Of the diploid cases, three were revised to complete mole and three to hydropic abortus.

\section{AgNOR ANALYSIS}

In complete mole, there were usually less than four AgNOR dots in the nuclei of villous trophoblast cells (fig 1G), whereas in partial mole there were often more than four (fig $1 \mathrm{H}$ ). The AgNOR count in hydropic abortuses closely resembled that in complete moles. The mean AgNOR count was highest in partial moles (5.11 (0.91)) followed by hydropic abortuses (3.79 (0.90)) and complete moles (3.39 (0.97)) (fig 2). The differences between mean AgNOR counts in partial mole versus 
complete mole and hydropic abortus were statistically significant (one factor ANOVA; $\mathrm{p}<0.0001)$. After consideration of the 75 th centile rate of mean AgNOR counts in all cases (fig 2), a mean count of $\geqslant 5$ was designated as a cut off limit for triploidy. Subsequently, nine of the 15 cases $(60 \%)$ with partial mole had a mean AgNOR count of $\geqslant 5$, while 10 each of 11 cases $(91 \%)$ with complete mole and hydropic abortus had a mean count of $<5$ (table 1). After reclassification, eight of the nine cases $(89 \%)$ with partial mole showed a mean AgNOR count of $\geqslant 5$.

COMPARISON OF INTERPHASE CYTOGENETIC AND AgNOR RESULTS

A high mean AgNOR count of 5.24 (0.73) was obtained in the total of 15 cases showing triploid patterns, while the count in 22 cases with diploid pattern was $3.50(0.88)$. The results of ploidy analyses by interphase cytogenetics and AgNOR count were closely correlated (Spearman rank correlation coefficient: $r$ $=0.73, \mathrm{z}=4.39, \mathrm{p}=0.0001)$.

\section{Discussion}

Nuclear ploidy analysis appears to play an important role in the diagnosis and classification of hydatidiform mole. ${ }^{9-12} 2425 \mathrm{In}$ this study, we examined and compared nuclear ploidy in histological sections of complete mole, partial mole, and hydropic abortus by interphase cytogenetics, using probes specific for chromosomes 1, X, and Y, and AgNOR count. We found that the results obtained by the two methods were closely correlated and provided useful information to supplement the histological distinction between complete mole, partial mole, and hydropic abortus. Hydatidiform mole is currently diagnosed and classified on a morphological and cytogenetic basis. Recently, flow cytometry has been successfully used to assess ploidy in hydatidiform mole. ${ }^{10-12}$ Flow cytometry quantifies the amount of nuclear DNA in a large fraction of particular cells relative to their normal counterparts, and is an established method of ploidy analysis. Image analysis of the nuclear DNA content of a certain cell type appears to be more accurate than flow cytometry as the cells are selected based on their morphology. ${ }^{32}{ }^{33}$ In flow cytometry, the amount of DNA in tumour cell nuclei must show at least $4 \%$ deviation to be distinguished from normal DNA. ${ }^{34}$ This amounts to the DNA content of two to three chromosomes, ${ }^{35} 36$ implying that two or three chromosomes have to be lost or gained before the change can be detected. Interphase cytogentic analysis using chromosome specific probes has been successfully used to detect numerical chromosome aberrations. ${ }^{16}{ }^{18} \mathrm{Re}-$ cently, Hopman et al developed a simplified protocol to perform in situ hybridisation using chromosome specific probes on paraffin embedded tissue sections from bladder tumours. ${ }^{13}$ They found a close correlation between chromosome copy numbers in paraffin sections and in cell suspensions of the same tumours. Subsequently, Van de Kaa et al applied the same method on paraffin sections from a series of hydatidiform mole and hydropic abortus for the assessment of chromosome ploidy and the determination of sex chromosome composition. ${ }^{14} 15$ They found a high value for this method in distinguishing partial mole from complete mole and hydropic abortus. A good correlation was also shown between the results obtained by interphase cytogenetics and DNA flow cytometry in partial mole and hydropic abortus. However, all cases with complete mole had a diploid pattern but with a high fraction of polyploid nuclei by interphase cytogenetic analysis, and also showed a polyploid pattern by DNA cytometry. Thus interphase cytogenetics can be successfully applied to paraffin sections to identify chromosomal aberrations in nuclei with minor DNA changes undetectable by DNA cytometry.

On the other hand, recent studies on AgNOR in breast carcinomas have shown a close correlation between the mean number of AgNOR and flow cytometric assessment of nuclear ploidy. ${ }^{2122}$ In addition, Giri et al found that approximately three quarters of breast tumours with AgNOR counts of more than 3 had significant aneuploid cell populations and showed a strong correlation between the AgNOR count and nuclear ploidy. ${ }^{37}$ Suresh et $a l,{ }^{23}$ in a study of trophoblastic tissue, showed that in non-neoplastic trophoblastic tissue AgNOR counts are clearly a reflection of ploidy rather than cell proliferation. Therefore the AgNOR count appears to be a promising tool for assessment of nuclear ploidy. These observations prompted us to evaluate formalin fixed, paraffin embedded tissue specimens from a series of complete moles, partial moles, and hydropic abortuses for nuclear ploidy by interphase cytogentics using in situ hybridisation and AgNOR count.

In our series, the diagnosis of partial mole was confirmed in nine of 15 cases $(60 \%)$ following histological examination and ploidy analyses by interphase cytogenetics and AgNOR count. In the remaining six cases, the diagnosis was revised to complete mole in three cases and hydropic abortus in three cases. Bagshawe et al found that in five of 11 partial mole cases $(45 \%)$ the diagnosis of partial mole could be confirmed after histological examination and DNA ploidy analysis. ${ }^{2}$ In the remaining six cases, the diagnosis was revised to complete mole in four and non-molar pregnancy in two cases. In another study, $55 \%$ of partial mole cases were DNA triploid. ${ }^{15}$ In the present study, eight of the 11 cases ( $73 \%$ ) each of complete mole and hydropic abortus were confirmed to be diploid. The remaining three cases of each group were triploid. Two of the triploid complete mole and one of the triploid hydropic abortus cases were revised to partial mole. The remaining one triploid complete mole was revised to hydropic abortus. These findings signify the importance of the combined use of conventional histology and ploidy analyses in the differential diagnosis of complete mole, partial mole, and hydropic abortus.

Interphase cytogenetic and AgNOR methods do not require fresh tissue, cell culture, metaphase spread, or isolation of a certain cell 
type. However, some factors inherent in paraffin sections-such as slicing through a portion of each nucleus which may result in an apparent loss of chromosomes or AgNOR dots, and nuclear overlapping-should be considered. These factors may affect the accuracy of signal $^{34}$ or AgNOR enumeration. Nevertheless, the two methods are highly reproducible and reliable for detection of nuclear ploidy in tissue sections. ${ }^{13-15} 1718$ 21-23

In conclusion, although larger studies are required, our data suggest that interphase cytogenetics by in situ hybridisation using chromosome specific probes and AgNOR count offer useful approaches for ploidy analysis in histological sections of hydatidiform mole. In our opinion, in addition to flow cytometry, these methods are also useful in resolving unclassifiable cases of hydatidiform mole.

We wish to thank professor Kaoru Aihara, Director, Centra Institute for Electron Microscopic Researches, Nippon Medical School, for his supports and Mr Yoshihiro Sasaki for technical assistance. Thanks are also due to professor Yuichi Sugisaki, Department of Pathology, Nippon Medical School, for providing the paraffin blocks of the patients.

1 Bracken MB. Incidence and aetiology of hydatidiform mole: an epidemiological review. $B r \quad \mathcal{f}$ Obstet Gynaecol 1987;94:1123-35.

2 Bagshawe KD, Lawler SD, Paradinas FJ, et al. Gestational trophoblastic tumours following initial diagnosis of partial hydatidiform mole. Lancet 1990;335:1074-6.

3 Fisher RA, Povey S, Jeffreys AJ, et al. Frequency of heterozygous complete hydatidiform moles, estimated by locus-specific minisatellite and $\mathrm{Y}$ chromosome-specific probes. Hum Genet 1989;82:259-63.

4 Lawler SD, Pickthall VJ, Fisher RA, et al. Genetic studies of complete and partial hydatidiform moles. Lancet 1979;ii: 580 .

5 Ohama K, Kaji T, Okamoto E, et al. Dispermic origin of XY hydatidiform moles. Nature 1981;296:551-2.

6 Kajii T, Ohama K. Androgenic origin of hydatidiform mole. Nature 1987;268:633-4.

7 Szulman AE, Surti U. The syndromes of hydatidiform mole I. Cytogenetic and morphologic correlations. Am $\mathcal{F}$ Obste Gynecol 1978;131:665-71.

8 Szulman AE, Surti U. The syndromes of hydatidiform mole. II. Morphologic evolution of the complete and partial mole. Am 7 Obstet Gynecol 1978;132:20-7.

9 Shepard TH, Fantel AG. Embryonic and early fetal loss. Clin Perinatol 1979;6:219-43.

10 Fisher RA, Lawler SD, Ormerod MG, et al. Flow cytometry used to distinguish between complete and partial hydatidiform moles. Placenta 1987;8:249-56.

11 Lage JM, Driscoll SG, Yavner DL, et al. Hydatidiform moles: application of flow cytometry in diagnosis. $A m \mathcal{F}$ Clin Pathol 1988;89:596-600.

12 Benirschke K. Flow cytometry for all mole-like abortion specimens. Hum Pathol 1989;20:403-4.

13 Hopman AHN, Van Hooren E, Van de Kaa CA, et al. Detection of numerical chromosome aberrations using in situ hybridization in paraffin sections of routinely processed bladder cancers. Mod Pathol 1991;4:503-13.

14 Van de Kaa CA, Nelson KAM, Ramaekers FCS, et al. Interphase cytogenetics in paraffin sections of routinely processed hydatidiform moles and hydropic abortions. $f$ Pathol 1991;165:281-7

15 Van de Kaa CA, Hanselaar AGJM, Hopman AHN, et al. DNA cytometric and interphase cytogenetic analysis of paraffin-embedded hydatidiform moles and hydropic abortions. F Pathol 1993;170:229-38.
16 Harrison M, Magee HM, O'Loughlin J, et al. Chromosome 1 aneusomy, identified by interphase cytogenetics, in mamaneusomy, identified by interphase cytogenetics, in mamographically detected ductal car

7 Cremer T, Landegent J, Bruckner A, et al. Detection of chromosome aberrations in the human interphase nucleus by visualization of specific target DNAs with radioactive and non-radioactive in situ hybridization techniques: diagnosis of trisomy 18 with probe L1.84. Hum Genet 1986;74: 346-52.

18 Devilee P, Thierry RF, Kievits T, et al. Detection of chromosome aneuploidy in interphase nuclei from human primary
breast tumors using chromosome-specific repetitive DNA probes. Cancer Res 1988;48:5825-30.

19 Wachtler F, Hopman AH, Wiegant J, et al. On the position of nucleolus organizer regions (NORs) in interphase nuclei. Exp Cell Res 1986;167:227-40.

20 Crocker J, Skilbeck N. Nucleolar organiser region associated proteins in cutaneous melanotic lesions: a quantitative proteins in cutaneous melanotic
study. $\mathcal{F}$ Clin Pathol 1987;40:885-9.

21 Mourad WA, Erkman-Balis B, Livingston S, et al. Argyrophilic nucleolar organizer regions in breast carcinoma: correlation with DNA flow cytometry, histopathology, and ymph node status. Cancer 1992;69:1739-44.

22 Mourad WA, Setrakian S, Hales ML, et al. The argyrophilic nucleolar organizer regions in ductal carcinoma in situ of the breast. Cancer 1994;74:1739-45.

23 Suresh UR, Chawner L, Buckley CH, et al. Do AgNOR counts reflect cellular ploidy or cellular proliferation? A study of trophoblastic tissue. F Pathol 1990;160:213-15.

24 Szulman AE, Philippe E, Boue JG, et al. Human triploidy: association with partial hydatidiform moles

25 Paradinas FJ, Browne P, Fisher RA, et al. A clinical, histopathological and flow cytometric study of 149 complete moles, 146 partial moles and 107 non-molar hydropic abortions. Histopathology 1996;28:101-9.

26 Cooke HJ, Hindley J. Cloning of human satellite III DNA: different components are on different chromosomes. Nucleic Acids Res 1979:6:3177-97.

27 Rocchi M, Roncuzzi L, Santamaria R, et al. Mapping through somatic cell hybrids and cDNA probes of protein $\mathrm{C}$ to chromosome 2, factor X to chromosome 13, and alpha 1-acid glycoprotein to chromosome 9. Hum Genet 1986;74: 30-3.

28 Cooke HJ, Schmidtke J, Gosden JR. Characterization of a human Y chromosome repeated sequence and related sequences in higher primates. Chromosoma 1982;87:491502.

29 Henke RP, Ayhan N. Enhancement of hybridization efficiency in interphase cytogenetics on paraffin-embedded tissue sections by microwave treatment. Anal Cell Pathol 1994;6:319-25.

30 Sperry A, Jin L, Lloyd RV. Microwave treatment enhances detection of RNA and DNA by in situ hybridization. Diagn detection of RNA and DNA

31 Ghazizadeh M, Sasaki Y, Araki T, et al. Prognostic value of proliferative activity of ovarian carcinoma as revealed by PCNA and AgNOR analyses. Am f Clin Pathol 1997;107: 451-8.

32 Shankey TV, Kallioniemi OP, Koslowski JM, et al. Consensus review of the clinical utility of DNA content cytometry in prostate cancer. Cytometry 1993;14:497-500.

33 Wilbur DC, Zakowski MF, Kosciol CM, et al. DNA ploidy in breast lesions. A comparative study using two commercial image analysis systems and flow cytometry. Anal Quant Cytol Histol 1990;12:28-34.

34 Persons DL, Takai K, Gibney DJ, et al. Comparison of fluorescence in situ hybridization with flow cytometry and static image analysis in ploidy analysis of paraffinsmbedded prostate adenocarcinoma. Hum Pathol 1994;25: 678-83.

35 Carey FA. Measurement of nuclear DNA content in histological and cytological specimens: principles and applications. F Pathol 1994;172:307-12.

36 Cajulis RS, Kotliar S, Haines GK, et al. Comparative study of interphase cytogenetics, flow cytometric analysis, and nuclear grade of fine-needle aspirates of breast carcinoma. Diagn Cytopathol 1994;11:151-8.

37 Giri DD, Nottingham JF, Lawry J, et al. Silver-binding nucleolar organizer regions (AgNORs) in benign and malignant breast lesions: correlations with ploidy and growth phase by DNA flow cytometry. F Pathol 1989;157: 307-13. 